\title{
RESPIRATORY SYMPTOMS AND PULMONARY FUNCTIONS AMONG AUTOMOBILE REPAIR WORKERS
}

\author{
By \\ Khashaba EO, El-Gilany A and Albadry AA \\ Department of Public Health and Community Medicine, Faculty of Medicine, \\ Mansoura University, Egypt \\ Corresponding author: Khashaba EO.Email:emankhashaba@mans.edu.eg
}

Submit Date: 2020-10-16

Revise Date: $2020-12-16$

Accept Date: 2020-12-23

DOI: 10.21608/ejom.2020.46291.1215

Authors' contribution: Authors contributed equally to this work.

\begin{abstract}
Introduction: Car repair technicians use chemicals during their work. These chemicals become airborne during its application and can be easily inhaled and cause harm to the respiratory system. Aim of work: The current study aims to describe the magnitude of respiratory symptoms and pulmonary function disorders among automobile repair workers. Materials and Methods: A cross-sectional descriptive study was performed on 121 automobile repair workers. The workers completed a predesigned questionnaire to collect socio-demographic data, including occupational history, special habits, and respiratory complaints. The pulmonary function tests were carried out utilizing SpirolabIII from MIR Company with Winspiro Pro software, a calibrated spirometer with a built-in computer program. Forced vital capacity (FVC), forced expiratory volume in one second (FEV1), and the ratio of these variables (FEV1/FVC) was measured as a percentage of normal predicted levels according to age, gender, weight, and height. Results: Dry cough and chest tightness were the most common respiratory symptoms ( $33.9 \%$ and $23.1 \%$, respectively); however, only $4 \%$ of the automobile repair workers used respiratory protective equipment. More than one-third $(38.8 \%)$ of the subjects had pulmonary function (PF) disorders (19\% with obstructive patterns and $19.8 \%$ with restrictive patterns). Pulmonary function disorders were common among the older $(>30$
\end{abstract}


years), compared to the younger age group ( $\leq 30$ years) ( $48.1 \%$ vs. $22.7 \%$, respectively) and workers who are exposed to brake fluid. Smoking, obesity, and a long duration of employment had no significant associations with PF disorders. Conclusion: The current study showed that two out of five car mechanics exhibited changes in pulmonary functions that were equally distributed between obstructive and restrictive impairments. Pulmonary function disorders were common among the older age group, regardless of smoking or a long employment duration. The promotion of workplace safety and the periodic spirometry examination of individuals is required to detect any respiratory changes.

Keywords: Automobile repair workers, Pulmonary complaints, Obstructive pulmonary functions, Restrictive pulmonary functions and Car mechanics.

\section{Introduction}

Repair technicians, otherwise known as mechanics, are accustomed to apply chemicals that can be hazardous to perform repairs on vehicles. The application of chemicals typically involves spraying aerosolized agents onto a part or surface (Spencer et al., 2007). A case control study in Nigeria found that the automobile painters showed significant decrease in lung functions compared with control group indicating airway obstruction (James et al., 2019).

Workers in the motor vehicle repair industry are frequently exposed to particulate matter (soot), carbon monoxide, inorganic solvents, welding fumes, isocyanates in paints, and heavy metal poisoning (Kumar and George, 2017). These various agents are inhaled from the environment, and the interaction of these factors in the tissues of the lungs airways' results in many lung diseases (Gupta et al., 2016)
Respiratory morbidity is common among vehicle repair workers. Chronic exposure to the previously described factors may lead to occupational asthma or chronic obstructive pulmonary diseases (Eisen et al., 2001). Previous studies have reported abnormal pulmonary functions among car maintenance workers in India (Chattopadhyay, 2007; Philip et al., 2014; Kumar and George, 2017). However, the types of pulmonary function disorders (obstructive or restrictive disorders) vary according to occupational exposures' patterns.

In Egypt, there is no occupational health and safety program to the informal sector of car mechanics. Adequate data regarding occupational respiratory diseases in this group are necessary to identify the diseases and implement safety measures. Despite this need, few epidemiologic studies on unorganized workers who experience 
occupational exposure in Egypt's vehicle repair industry. One was conducted to determine the prevalence of occupational injuries in young automobile workers (12-18 years) and its associated factors in Port-said city (Abdellah and Morsy, 2013). Another one was carried out to assess the prevalence of occupational dermatoses and their possible risk factors on a convenience sample of car mechanics in Mansoura city (Abou-Elwafa et al., 2018). There are no published studies on respiratory complaints and pulmonary function among automobile repair workers in Mansoura city to the best of the authors' knowledge.

\section{Aim of work}

The current study was carried out to describe the magnitude of respiratory symptoms and pulmonary function disorders among automobile repair workers in Mansoura city, Egypt.

\section{Materials and Methods}

Study design: This is a descriptive cross-sectional study

Place and duration of study: The study was carried out from June to August 2018 in car maintenance workshops in the Sandoub and Magazar regions in Mansoura city, Egypt.
Study Sample: A nonprobability sample of 148 automobile repair workers was selected via the snowball sampling method. The workers were invited to participate in the study, and 121 workers completed the questionnaire (response rate: $81.8 \%$ ). The sample included body repair workers, automobile electricians, welders, motor engine repair workers, spray painters, and others (service workers) who passed at least one year in their work.

\section{Study methods:}

-A predesigned questionnaire was completed during each interview to collect socio-demographic data, occupational history, history of special habits, data on workplace exposure to physical, mechanical, and chemical hazards, personal protective measures used, and any respiratory complaints. Weight and height were measured, then body mass index was calculated. Obesity was defined as BMI $\geq 30$ (calculated by dividing the weight in kilograms by the square of height in meters $\left.\left(\mathrm{kg} / \mathrm{m}^{2}\right)\right)(\mathrm{CDC}, 2017)$.

\section{-The pulmonary function tests} were carried out on the site in a nearby office used for administrative work. The test was done using portable SpirolabIII from MIR Company with Winspiro 
Pro software, a calibrated spirometer with a built-in computer program, by utilizing standard laboratory methods.

All the subjects were familiarized with the equipment and the procedure before the pulmonary function tests' performance. The study subjects were comfortably seated in an upright position with their heads situated within the Frankfurt plane. During the tests, study subjects were asked to insert the mouthpiece, and the transducer in the mouth and nose clip was applied. For each study subject, the mouthpiece was single-use. The participants were adequately encouraged to perform rapid, deep inspiration followed by rapid, deep expiration.

Once the lungs'airhadbeen expelled, each subject breathed as quickly as possible (with the transducer still placed in the mouth) until the lungs were full. One single expiratory effort provided readings about many parameters. The following were measured and selected for the study: forced expiratory volume in one second $\left(\mathrm{FEV}_{1}\right)$, forced vital capacity (FVC), and the ratio of these parameters $\left(\mathrm{FEV}_{1} / \mathrm{FVC}\right.$ ratio), which was expressed as a percentage. Three readings were taken for each parameter, and the highest value was recorded for each of the parameters. The FVC,
$\mathrm{FEV}_{1} 1$, and $\mathrm{FEV}_{1} / \mathrm{FVC}$ were expressed as percentages of the predicted values to the reference controls based on age, gender, weight, and height parameters. Spirometry data interpretation included normal pattern (defined as a normal $\mathrm{FVC}$, normal $\mathrm{FEV}_{1} / \mathrm{FVC}$ ratio, and normal total lung capacity [TLC]), an obstructive pattern (defined as a reduced FEV1/FVC ratio, below the lower limit of normal (LLN), with a normal FVC and normal TLC (Patouchas et al., 2008), and a restrictive pattern (defined as a reduced TLC below the lower limit of $95 \%$ confidence interval (CI), especially in subjects with an $\mathrm{FVC} \leq 85 \%$ of the predicted value and an $\mathrm{FEV}_{1} /$ FVC ratio $\leq 55 \%$ of the predicted value) (Aaron et al., 1999).

\section{Consent}

Study subjects provided informed consent to voluntarily participate in the study, with a full right to withdraw at any time and the assurance of confidentiality and anonymity of the data.

\section{Ethical approval}

The Institutional Ethical Committee Board of the Department of Public Health and Community Medicine, Faculty of Medicine, Mansoura University, approved the study (review board (R.18.03.95)). 


\section{Data management}

Data were entered and analyzed using SPSS version 20. Qualitative data were described as numbers and percentages. Chi-squared or Fisher's exact tests were used for comparison between groups, as appropriate. Quantitative data were described as the means and standard deviations for normally distributed variables and as medians for nonparametric variables. $\mathrm{P}$ values $\leq \mathbf{0 . 0 5}$ were considered as statistically significant.

\section{Results}

Table (1): Some demographic characteristics of the studied automobile repair workers.

\begin{tabular}{|c|c|}
\hline Variables & Studied subjects $(\mathrm{No}=121)$ No $(\%)$ \\
\hline $\begin{array}{l}\text { Age / years } \\
<20 \\
20-29 \\
30-39 \\
40-49 \\
\geq 50 \\
\text { Median (min-max) }\end{array}$ & $\begin{array}{l}18(14.9) \\
23(19) \\
28(23.1) \\
20(16.5) \\
32(26.4) \\
35(9-77)\end{array}$ \\
\hline $\begin{array}{l}\text { Body mass index (BMI) } \\
\text { Mean (SD) }\end{array}$ & $26.4(4.9)$ \\
\hline $\begin{array}{l}\text { Education } \\
\text { Illiterate } \\
\text { Basic education } \\
\text { Secondary school } \\
\text { High education }\end{array}$ & $\begin{array}{c}60(49.6) \\
27(22.3) \\
24(19.8) \\
10(8.3)\end{array}$ \\
\hline $\begin{array}{l}\text { Marital status } \\
\text { Single/divorced/widow } \\
\text { Married }\end{array}$ & $\begin{array}{l}41(33.9) \\
80(66.1)\end{array}$ \\
\hline Current smokers ${ }^{\# \#}$ & $72(59.5)$ \\
\hline
\end{tabular}

All the automobile repair workers were males, with a median age of 30 years. Nearly half (49.6\%) of the subjects were illiterate, and $66.1 \%$ of the subjects had married at some time, and approximately two thirds $(59.5 \%)$ of the subjects were smokers (Table 1). 
Table (2): Work profiles and hazards among the studied automobile repair workers

\begin{tabular}{|c|c|}
\hline Work profile & $\begin{array}{c}\text { Studied subjects }(\mathrm{No}=121) \\
\text { No }(\%)\end{array}$ \\
\hline $\begin{array}{l}\text { Job description } \\
\text { General vehicle repair } \\
\text { Auto electrician } \\
\text { Welder } \\
\text { Motor engine repair } \\
\text { Painters } \\
\wedge \text { others }\end{array}$ & $\begin{array}{c}43(35.5) \\
10(8.3) \\
18(14.9) \\
13(10.7) \\
12(9.9) \\
25(20.7)\end{array}$ \\
\hline $\begin{array}{l}\text { Duration of employment/years } \\
\leq 20 \\
>20\end{array}$ & $\begin{array}{l}84(69.4) \\
37(30.6)\end{array}$ \\
\hline $\begin{array}{l}\text { Work hours } \\
\text { Full time ( } 8 \text { hours }) \\
\text { Part-time ( } 5 \text { hours })\end{array}$ & $\begin{array}{l}74(61.2) \\
47(38.8)\end{array}$ \\
\hline \# Use of PPE & $48(39.7)$ \\
\hline \#\# Occupational Hazards & \\
\hline $\begin{array}{l}\text { Physical Hazards } \\
\text { Heat } \\
\text { Moisture } \\
\text { Vibration } \\
\text { Electrical Hazards } \\
\text { Cold } \\
\text { Ultraviolet radiation }\end{array}$ & $\begin{array}{c}47(38.8) \\
30(24.7) \\
27(22.3) \\
17(14.0) \\
2(1.7) \\
1(0.8)\end{array}$ \\
\hline $\begin{array}{l}\text { Chemical Hazards } \\
\text { Heavy metals } \\
\text { Solvents } \\
\text { Lubricants } \\
\text { Fuel } \\
\text { Brake fluids } \\
\text { Paints }\end{array}$ & $\begin{array}{l}46(38.0) \\
33(27.3) \\
29(24.0) \\
28(23.1) \\
20(16.5) \\
15(12.4)\end{array}$ \\
\hline
\end{tabular}

$\wedge$ Others: service workers.

\#:PPE (not mutually exclusive): gloves (4), masks (2), helmets (19), coveralls (48), safety shoes (44). \#\#: Occupational hazards: categories are not mutually exclusive (Physical \& chemical hazards). 
Table2 showed that most of the workers were full-time $(61.2 \%)$, with a working duration of less than 20 years (69.4\%), and approximately $40 \%$ of them used personal protective equipment (PPE), which mainly consisted of overalls and safety shoes. The most common physical hazards consisted of excess heat, moisture, and vibrations (38.8\%,24.7\% , and $22.3 \%$, respectively). The most commonly reported chemical hazards included heavy metals, solvents, and lubricants $(38.0 \%, 27.3 \%$ and $24 \%$, respectively).

Table (3): Respiratory findings among the studied automobile repair workers.

\begin{tabular}{|l|c|}
\hline \multicolumn{1}{|c|}{ Respiratory findings } & Studied subjects (No=121) \\
No (\%)
\end{tabular}

\#:Obstructive: Mild (20). Moderate (2) and Severe (1)

\#\#:Restrictive: Mild (13), Moderate (7) and Severe (4)

Dry cough and chest tightness were the most common respiratory symptoms (33.9\% and $23.1 \%$, respectively). Nineteen percent of the study subjects had obstructive PF, and $19.8 \%$ of the subjects had restrictive PF (Table 3)

Auto electricians had lower FVC and FEV1 values, compared with the other job descriptions, with no statistically significant differences observed. Additionally, motor engine repair workers had reduced FEV1 $\backslash$ FVC ratios than the other job descriptions, with no statistically significant differences observed (Data are not tabulated). 
Table (4): Determinants of pulmonary function disorders among the studied workers

\begin{tabular}{|c|c|c|c|}
\hline \multirow[b]{2}{*}{ Variables } & \multicolumn{2}{|c|}{ Pulmonary Function Disorders } & \multirow[b]{2}{*}{$\underset{\text { value }}{p}$} \\
\hline & $\begin{array}{c}\text { Normal } \\
(\text { No }=74) \\
\text { No }(\%)\end{array}$ & $\begin{array}{c}\text { Abnormal } \\
(\text { No }=47) \\
\text { No }(\%)\end{array}$ & \\
\hline $\begin{array}{l}\text { Age / years } \\
\leq 30 \\
>30\end{array}$ & $\begin{array}{l}34(77.2) \\
40(51.9)\end{array}$ & $\begin{array}{l}10(22.7) \\
37(48.1)\end{array}$ & $0.006^{*}$ \\
\hline $\begin{array}{l}\text { Obesity } \\
\text { Non-obese } \\
\text { Obese }\end{array}$ & $\begin{array}{l}59(62.7) \\
15(55.5)\end{array}$ & $\begin{array}{l}35(37.3) \\
12(44.5)\end{array}$ & 0.4 \\
\hline $\begin{array}{l}\text { Duration of employment /years } \\
\leq 20 \\
>20\end{array}$ & $\begin{array}{c}53(63) \\
21(56.7)\end{array}$ & $\begin{array}{c}31(37) \\
16(43.3)\end{array}$ & 0.5 \\
\hline $\begin{array}{l}\text { Smoking } \\
\text { Smokers } \\
\text { Non-smokers }\end{array}$ & $\begin{array}{l}44(61.1) \\
30(61.2)\end{array}$ & $\begin{array}{l}28(38.9) \\
19(38.8)\end{array}$ & 0.9 \\
\hline \multicolumn{4}{|l|}{ Job description } \\
\hline $\begin{array}{l}\text { General vehicle repair } \\
\text { Auto electrician } \\
\text { Welder } \\
\text { Motor engine repair } \\
\text { Painters } \\
\text { Others }\end{array}$ & $\begin{array}{c}26(60.5) \\
8(80) \\
10(55.5) \\
5(38.5) \\
8(66.6) \\
17(68)\end{array}$ & $\begin{array}{c}17(39.5) \\
2(20) \\
8(44.5) \\
8(61.5) \\
4(33.4) \\
8(32)\end{array}$ & 0.3 \\
\hline \multicolumn{4}{|l|}{ Chemical exposure } \\
\hline Heavy metals & $28(60.8)$ & $18(39.2)$ & 0.9 \\
\hline Solvents & $19(57.5)$ & $14(42.5)$ & 0.6 \\
\hline Fuel & $16(57.2)$ & $12(42.8)$ & 0.6 \\
\hline Paints & $10(66.7)$ & $5(33.3)$ & 0.6 \\
\hline Lubricants & $18(62.1)$ & $11(37.8)$ & 0.9 \\
\hline Brake fluid & $9(45)$ & $11(55)$ & 0.1 \\
\hline
\end{tabular}

*: Statistically significant 
Table 4 showed that pulmonary function disorders were statistically significantly higher among the older age group ( $>30$ years), compared with the younger ones ( $\leq 30$ years) $(48.1 \%$ vs. $22.7 \%$, respectively). Also it were higher among motor engine repair workers and workers exposed to brake fluid although statistically non-significant ( $\mathrm{p}>0.05)$.

\section{Discussion}

Automobile mechanics are exposed to organic and inorganic substances present in petrol and diesel. They were complaining of chronic cough, wheezes, and breathlessness. However, there is limited published data regarding the pulmonary function test abnormalities among them (Anupama,2012).

The present study demonstrated that approximately $40 \%$ of automobile repair workers used PPE that mainly consisted of safety shoes and coveralls. Most of them were not protected against respiratory hazards, as only $4.16 \%$ of the mechanics used masks or respirators (Table 2). This finding could be attributed to the workers' low education level, with a lack of awareness of the importance of using protective equipment (Sambo et al., 2012). A cross-sectional study was carried out in Mansoura, Egypt by Abou-Elwafa et al., 2018 and reported that few car mechanics used masks and respirators. However, an Indian study about the prevalence of respiratory symptoms in automobile spray painters of Mumbai declared that, although 60\% of the workers were aware of the safety measures, only 33\% were applying them (Nahar and Ashraf, 2018).

The current study revealed that the most commonly reported chemical hazards were heavy metals, solvents, and lubricants (Table 2). These results were similar to the factsheet published by the International labor office (ILO) (2000), which reported that car mechanics are exposed to a wide range of industrial chemicals, including heavy metals, contained in brake fluids, degreasers, detergents, lubricants, metal cleaners, paints, fuel, solvents, etc., resulting in various forms of chronic poisoning.

In addition, these results were in agreement with the results of the study conducted in the urban area of Bangalore, who reported that automobile repair industry workers are exposed to particulate matter (soot), carbon monoxide, welding fumes, inorganic solvents, isocyanates in paints and heavy metal poisoning 
(Thangaraj and Shireen, 2016like work-related injuries, chronic illness, stress and, disability because of their low literacy rates, following unsafe practices, unfamiliarity with work process and exposures, and inadequate training. Objectives: 1. To assess the occupational health hazards among roadside automobile mechanics in an urban area of Bangalore 2. To assess the awareness of personal protective equipments among automobile mechanics. Materials and Methods: A cross sectional study was carried out for a period of 3 months, during September, October and November 2015 among 150 mechanics working at the automobile workshops in an urban area of Bangalore. Data was collected using a pre-tested, validated, semi-structured, indigenous, interviewer based questionnaire. Data was entered in Microsoft excel sheet and analyzed using SPSS 21 software. Descriptive statistics such as frequency tables, pie diagrams and bar charts were used wherever necessary. Result: Musculoskeletal diseases were the most commonly reported health problems by the mechanics $(n=93,62 \%)$.

A study from Pakistan demonstrated that metal contents in soil samples surrounding auto body shops were mainly contaminated due to metal pigments' exposure. The silent increase in metal concentrations in soil samples may contribute to the accumulation of heavy metals in humans (Tahir et al., 2010).

Dry cough and chest tightness were the most common respiratory complaints (33.9\% and $23.1 \%$, respectively) among the studied workers (Table 3). The same results were obtained by Philip et al., 2014 , in their study on morbidity among automobile service and repair workers in South India's urban area. These results may lead to impaired pulmonary function that could be attributed to occupational exposure.

The current study revealed that nearly one-fifth of the study subjects had obstructive lung disorders (19\%) and that another one-fifth had restrictive lung disorders (19.8\%) (Table 3). Also it showed that pulmonary functions disorders were higher among automobile workers exposed to brake fluid, although statistically non-significant (Table 4). FVC, FEV1, and the FEV $1 \backslash F V C$ ratio did not show any significant variations with car mechanics' job categories (data are not tabulated.).

A similar result of obstructive impairment was reported by Cullen 
et al, 1996 in England in their work on a feasibility study of respiratory questionnaire and peak flow recordings in shop workers exposed to isocyanatecontaining spray paint. A lower percentage $(16 \%)$ of reduced pulmonary function was reported by Philip et al., who found that this reduction was significantly associated with heavy metal exposure.

A cross-sectional work done in India studied the obstructive and restrictive disease patterns among 50 male spray painters aged 20 to 50 years exposed to spray paints for at least a year and they found that FVC and FEV1 were significantly reduced among spray painters (Seema et al., 2016).

In addition, a study on eighty-six vehicle body-spray painters in Nigeria reported that the values of peak expiratory flow rates (PEFR) before spray painting were significantly higher than the values after spray painting. Moreover, the values of PEFR of spray painters were significantly lower than the values of the control group with an average of about 92 L/min (Akanbi et al., 2018)

On the other hand, slightly higher rates of obstructive and restrictive impairments were reported in Pakistan (25.8\% and $21.19 \%$, respectively) by
Chattopadhyay (2007), as well as in India $(20.6 \%$ for obstructive, $25.8 \%$ for restrictive, and $10.3 \%$ for mixed lung functions disorders) by Kumar and George (2017) in their cross-sectional study on 97 automobile workers in the urban area of Raichur in India.

Moreover, in a study examining automobile repair workers, Parker et al. (1991) in their cross-sectional study of pulmonary function in autobody repair workers detected that obstructive impairment was evident among $26.3 \%$ of workers and that restrictive impairment was evident among $7.9 \%$ of workers.

These variations could be attributed to many factors, including differences in diagnostic methods, the type of spirometry used, operational definitions of both restrictive and obstructive impairments and differences in socio-demographic and occupational characteristics of the studied subjects, as well the levels of exposure to respiratory pollutants (Salvi et al., 1999).

The present work showed that pulmonary function disorders were more common among the older age group ( $>30$ years) than in the younger ones ( $\leq 30$ years) $(48.1 \%$ vs. $22.7 \%$, respectively) (Table 4$)$. - 
Eisen et al. (2001) in their study on respiratory health of automobile workers and exposures to metalworking fluid aerosols assessed the pulmonary function concerning to metal-working fluid (MWF) aerosols in a cross-sectional study on 1,811 male automobile workers. Exposure to these oils was significantly associated with decline in FVC. This association was more obvious among older workers and among workers who had never transferred from MWF exposed jobs to assembly. They concluded that the magnitude of the association between decline in FVC and lifetime exposure to straight MWF was larger than the estimated cigarette effect, suggesting that the impact of an additional year of exposure to $1 \mathrm{mg} / \mathrm{m}^{3}$ of mineral oil particulate in the thoracic particle size range, has the same impact on FVC as smoking one pack per day for one more year.

Also, Chattopadhyay et al. (2003) found in their study about pulmonary function abnormalities associated with exposure to automobile exhaust in a diesel bus garage and roads that pulmonary function tests values showed gradual decrement as age and duration of exposure increased.
Current study results also revealed that pulmonary function disorders showed non-significant differences with smoking and long working durations (Table 4). These results agreed with an Indian study done by Mandal and Majumder, 2014 on the pulmonary function of paint industry workers from West Bengal, India, that revealed a non-significant difference in pulmonary functions between smoking and non-smoking habits. Also Kumar and George, 2017 in their study on pulmonary function of automobile repair workers in the informal sector of Raichur urban ; concluded that the diseases from toxic exposures can take a long time to become apparent and are often not diagnosed as related to work experiences.

However, our results are different from the findings of Parker et al. (1991), Cullen et al. (1996), Chattopadhyay (2007), who reported more frequent obstructive impairments among smokers, with significant associations between decreases in the FEV1 and FVC and duration of work. Also, Zuskin et al. (1994) found that long-term employment in mechanics, particularly in combination with smoking, may be associated with developing chronic 
respiratory symptoms and lung function impairments.

Recommendations: The promotion of respiratory protection program is required to increase the awareness about the importance of personal respiratory protection. Also it is important to improve air quality by quantitative assessment of pollutants and encourage the use of industrial hygiene measures in such workshops, especially among workers with advanced ages.

Study limitations: This was a small-scale study on a nonprobability sample of car mechanics; therefore, the results cannot be generalized. Also, oximetry was not performed due to the contaminated hands of the workers. Another limitation was the lack of environmental measures due to the high cost. The possibility of selection bias due to the snowball sampling technique cannot be excluded.

\section{Conclusion}

Two out of five automobile repair workers exhibited pulmonary function disorders distributed between obstructive and restrictive impairments. Both obstructive and restrictive impairments increased in the older age group, regardless of smoking or long durations of employment. Less than half of the workers used PPE, and few of the workers used respiratory protection. The promotion of respiratory protection program is required to increase the awareness about the importance of personal respiratory protection.

\section{Conflict of interest}

None

\section{Funding}

None

\section{References}

1. Aaron SD, Dale RE and Cardinal P (1999): How Accurate Is Spirometry at Predicting Restrictive Pulmonary Impairment? CHEST;115(3):869-73. DOI: 10.1378/ chest.115.3.869.

2. Abdellah RF and Morsy KM (2013) : "Occupational Injuries among young workers in car repair workshops in Port Said, Egypt." Egypt J Occup Med; rv(2): 111-20.

3. Abou-ElWafa HS, Albadry AA, El-Gilany AH and Ismael AF (2018): Dermatoses among automobile mechanics in Mansoura, Egypt. Arch Environ Occup Heal-2;73(1):42-7. DOI: 10.1080/19338244.2017.1289892.

4. Akanbi OG, Ismaila SO, Nwosu CK and Oriolowo KT (2018): Effect of Respiratory Protection on Respiratory Flow Rates of Vehicle Spray Painters in Ibadan Metropolis, Oyo State, Nigeria. Ergonomics Int J ;2(2): 000139. DOI: 10.23880/eoij-16000139

5. Anupama N (2012): An Analysis of Dynamic Pulmonary Function in automobile mechanics. Int J Biomed Res ;3(8): 374-7. DOI: 10.7439/ ijbr.v3i8.714 
6. CDC (Centers for disease control and Prevention ) (2018): Defining Adult Overweight and Obesity . Available at https://www.cdc.gov/ obesity/adult/defining.html

7. Chattopadhyay BP, Alam J and Roychowdhury A (2003): Pulmonary function abnormalities associated with exposure to automobile exhaust in a diesel bus garage and roads. Lung; 181(5):291-302. DOI: 10.1007/s00408-0031033-y. PMID: 14705773.

8. Chattopadhyay O (2007): Pulmonary function in automobile repair workers'. Indian J Community Med; 32(1):40.DOI: 10.4103/09700218.53393.

9. Cullen MR, Redlich CA, Beckett WS, Weltmann B, Sparer J, et al.(1996): Feasibility study of respiratory questionnaire and peak flow recordings in autobody shop workers exposed to isocyanate-containing spray paint: Observations and limitations'. Occup Med;46(3):197-204. DOI: $10.1093 /$ occmed/46.3.197.

10. Eisen EA, Smith TJ, Kriebel D, Woskie SR, Myers DJ et al. (2001): Respiratory health of automobile workers and exposures to metalworking fluid aerosols: Lung spirometry. Am J Ind Med; 39(5): 443-53. DOI: 10.1002/ ajim.1038.

11. Gupta G, Yograj S, Gupta AK, Langer B and Goni M (2016): Forced vital capacity, forced expiratory volume in 1 st second and forced expiratory ratio in automobile spray paint workers'. Int J Res Med Sci; 4(9): 3724-8. DOI: 10.18203/2320-6012.ijrms20162602.

12. International Labor Office (ILO)(2000): International Hazard Datasheets on Occupation. Mechanic, automobile. Available at https:// www.ilo.org/wcmsp5/groups/public/---ed_ protect/---protrav/---safework/documents/ publication/wcms_193167.pdf Last accessed 2 December 2020.

13. James GO, Hamza WR and Lay YD (2019): Comparative Assessment of Lung Function using Peak Expiratory Flow Rate (PEFR) Between Automobile Painters and Non-Painters within Mechanic Garages In Farin-Gada, Jos, Plateau State, Nigeria. IOSR Journal of Dental and Medical Sciences (IOSR-JDMS) ;18(9):4450

14. Kumar MK and George LS (2017): Pulmonary function of automobile repair workers in the informal sector of Raichur urban'. Int J Community Med Public Health; 4(5):1510-4. DOI: 10.18203/2394-6040.ijcmph20171571.

15. Mandal (Majee) A and Majumder R (2013): Pulmonary function of Paint Industry workers from West Bengal, India. Prog Health Sci ; 3 (2):110-21.

16. Nahar S and Ashraf M (2018): Prevalence of respiratory symptoms in automobile spray painters of Mumbai: A cross-sectional study. Int Arch Allergy Immunol; 32(2):54. DOI: 10.4103/ijaai.ijaai_10_18.

17. Parker DL, Waller K, Himrich B, Martinez A, and Martin F (1991): A cross-sectional study of pulmonary function in autobody repair workers. Am J Public Health; 81(6): 768-71. DOI: 10.2105/AJPH.81.6.768.

18. Patouchas D, Efremidis G, Karkoulias K, Zoumbos N, Goumas, P , et al.(2008): Lung function measurements in traditional bakers'. Acta Biomedica de l'Ateneo Parmense;79(3):197-203.

19. Philip M, Alex, R G, Sunny SS, Alwan, A, Guzzula, D and Srinivasan R (2014): A study on morbidity among automobile service and repair workers in an urban area of South India . Indian J Occup Environ Med; 18(1) 9-12. DOI: 10.4103/0019-5278.134946.

20. Salvi S, Blomberg A, Rudell B, Kelly F, Sandstrom T, et al. (1999): Acute inflammatory responses in the airways and peripheral blood after short-term exposure to diesel exhaust in healthy human volunteers'. Am J Respir Crit Care Med; 159(3):702-9. DOI: 10.1164/ 
ajrccm.159.3.9709083.

21. Sambo MN, Idris SH and Shamang A (2012): Determinants of Occupational Health Hazards among Roadside Automobile Mechanics in Zaria, North-Western Nigeria'. Borno Medical Journal; 9(1): 5-9.

22. Seema TM and Karandikar MS(2016): A Study of Pulmonary Functions of Spray Painters Working In Automobile Garage. IOSR Journal of Dental and Medical Sciences (IOSR-JDMS); 15(3):1-7.

23. Spencer JW ,Plisko L and Marc J (2007): “A Comparison Study Using a Mathematical Model and Actual Exposure Monitoring for Estimating Solvent Exposures During the Disassembly of Metal Parts." J Occup Environ Hyg; 4 (4):253
$-9$.

24. Tahir H, JahanZeb Q, and Sultan M (2010): Assessment of heavy metal exposure around auto body refinishing shops'. Afr J Biotechnol; 9(46), 7862-69

25. Thangaraj S and Shireen N (2017): Occupational health hazards among automobile mechanics working in an urban area of Bangalore - a crosssectional study'. Int J Med Sci Public Health; 6(1),18-23. DOI: 10.5455/ijmsph.201.

26. Zuskin E, Mustajbegovic $\mathrm{J}$ and Schachter EN (1994): Respiratory symptoms and lung function in bus drivers and mechanics'. Am J Ind Med; 26(6): 771-83. DOI: 10.1002/ ajim.4700260606. 
